\title{
CORRECTION
}

\section{American Academy of Neurology Code of Professional Conduct}

In the Special Article "American Academy of Neurology Code of Professional Conduct" by Russell et al. ${ }^{1}$, the following paragraph should have been included after the first paragraph in the Acknowledgement section:

The authors wish to acknowledge and express deep gratitude to the authors of the original code of professional conduct: James L. Bernat, MD, and H. Richard Beresford, MD, JD, in collaboration with the other then-current members of the AAN Ethics and Humanities Subcommittee. Drs. Bernat and Beresford's original document, much of which is preserved in this revised code, continues to be a highly valued, dynamic, and seminal work for neurology.

The authors regret the omission.

\section{REFERENCE}

${ }^{1}$ Russell JA, Hutchins JC, Epstein LG. American Academy of Neurology code of professional conduct. Neurology. 2021;97(10): 489-495.

Neurology® Published Ahead of Print articles have been peer reviewed and accepted for publication. This manuscript will be published in its final form after copyediting, page composition, and review of proofs. Errors that could affect the content may be corrected during these processes. 


\section{Neurology}

\section{American Academy of Neurology Code of Professional Conduct \\ Neurology published online October 4, 2021 \\ DOI 10.1212/WNL.0000000000012889}

This information is current as of October 4, 2021

\section{Updated Information \&}

Services

Subspecialty Collections

Permissions \& Licensing

Reprints including high resolution figures, can be found at:

http://n.neurology.org/content/early/2021/10/04/WNL.0000000000012889. citation.full

This article, along with others on similar topics, appears in the following collection(s):

Autonomic diseases

http://n.neurology.org/cgi/collection/autonomic_diseases

Information about reproducing this article in parts (figures,tables) or in its entirety can be found online at:

http://www.neurology.org/about/about_the_journal\#permissions

Information about ordering reprints can be found online:

http://n.neurology.org/subscribers/advertise

Neurology ${ }^{\circledR}$ is the official journal of the American Academy of Neurology. Published continuously since 1951, it is now a weekly with 48 issues per year. Copyright (C) 2021 American Academy of Neurology. All rights reserved. Print ISSN: 0028-3878. Online ISSN: 1526-632X.

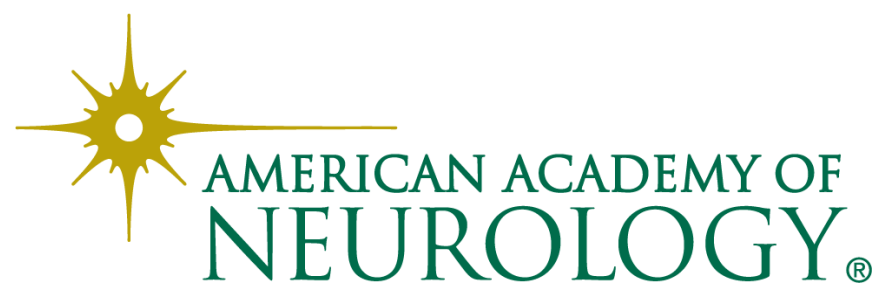

